\title{
OWNERS' DEMOGRAPHICS AND OWNERSHIP INFORMATION IN EXPLAINING CREDIT REPAYMENT BEHAVIOR OF MICRO SMALL AND MEDIUM SIZED ENTERPRISES
}

\author{
HM. Nijam \\ Department of Accountancy and Finance, Faculty of Management and Commerce \\ South Eastern University of Sri Lanka \\ nijamhm@seu.ac.lk
}

\begin{abstract}
Small Medium Enterprises (SMEs) in developing countries are subject to higher degree of information opacity causing substantive constrains on lenders in their pursuit of predicting credit risk associated with SME lending. Driven by this context, the lending for SMEs is often characterized as relationship lending and credit risk predictions therefore necessarily resort to qualitative information which is often deemed to be the cost effective, viable and technically sound alternative. Therefore, this research sought to investigate the influence of owners' demographic and ownership information of Micro and Small Medium sized Enterprises (MSMEs)in explaining their credit default risk using primary data collected from randomly selected 62 MSME borrowers from Trincomalee District of Sri Lanka. Owners demographics studied by gender, civil status, size of family, age and age group, ethnicity, education and mobility (the distance between lender and enterprise) of the owners' of MSMEs under study. Ownership information was proxied by the information whether the business is of soleproprietorship or partnership or of any other type. This study contributes to the literature a novel concept of Loan Repayment Risk Matrix (LRRM) as a comprehensive framework to approach credit repayment risk/credit default risk. Chi-Square Test has been employed to examine the relationship between dependent and independent variables and where the independent variables take continuous values (in the case of mobility), the difference of mean is
\end{abstract}

tested with one-way analysis of variance (ANOVA) with post hoc comparison using Turkey's honestly significant difference (HSD) test. It has been found that owners'gender, age, education, language and mobility and ownership information are significantly correlating with loan default risk of MSMEs and statistically significant relationship could not be found with respect to civil status, ethnicity and family size.

Key words: $S M E$, Micro Small and Medium Enterprises, Loan Default, Credit Risk, Trincomalee, Demographics

\section{Introduction}

Lending to Micro and Small Medium sized Enterprises (MSMEs) (the acronym SMEs and MSMEs have been interchangeably used in this study) is crucial for economic and social development on one hand, it is deemed to be highly riskier as lending decision on SME sector is characterized by higher asymmetry of information particularly in developing economies on the other.Though asymmetric information between borrowers and lenders is a general feature of all credit markets around the globe, it is acute in SME segment as information assisting default prediction are not often adequately, reliably and fairly disclosed by the SMEs. Lending decisions of financial institutions are not hence simply characterized by just the demand of borrowers for credit but it is a matter of comprehensive investigation of potential clients' credit repayment behaviors. 
Though, the evaluation of creditworthiness of the SME borrowers in particular is thus an important concern of all lending organizations, SMEs particularly in developing countries pose huge challenge for lenders in prediction of their credit worthiness as they are in informationally opaque market. As Berger and Udell (2006) mention it is due to lack of audited financial statements, commingling of the owner's personal finances and those of the business and because of their diversity. The problem of information opacity is more acute when loan applicants are from micro and small enterprises. Lenders therefore rely on different lending technologies for assessing borrowers' creditworthiness. All lending technologies are ultimately sought for prudent lending by predicting the possibility of credit repayment or defaults by borrowers.

Berger and Udell (2006) categorized lending technologies into two types which are transactions lending that is based primarily on "hard" quantitative data and relationship lending, which is based significantly on "soft" qualitative information and it is designed to address information problems that are not feasible or cost-effectively solved by the other technologies. Under this categorization, transactions lending is generally viewed as being focused on informationally transparent borrowers, while relationship lending is seen as used for informationally opaque borrowers. Relationship lending is the one which is often identified as most feasible approach when it comes for the small business loan environment.

Various lending technologies and credit risk prediction models are sought for the prediction of risk factor in a SME lending decision primarily based on the information pertinent to the organization and its business and governance. Thus, such lending technologies and risk models evolve around the business and the organization corresponding to the borrower/s. However, the studies on credit repayment behavior appear to investigate creditworthiness of borrowers primarily based on information that may characterize the borrowers' attitudes about loan repayment. Thus, studies on credit repayment behaviore volve primarily around the personal and environmental factors that might have influence on borrowers' attitudes on repayments. The current literature appears to lack a cohesive and conclusive framework for analyzing micro small medium enterprises' loan default characteristics on one hand and lending institutions that service small and medium business segment in developing countries like Sri Lanka cannot reasonably be expected on the other to employ sophisticated default prediction models and techniques to assess credit worthiness of SME clients whose financial reporting practices are largely substandard and or not easily accessible. Yet, before underwriting a loan to borrowers of any type, all lenders are performing a risk assessment using their own methodologies developed through their practice over time. Commonly said, there are two types of risk analysis which are quantitative and qualitative. According to Coravos (2010), loan officers perform a qualitative risk analysis when they interview the potential borrower, look over the business plan (if available) and review past financial history. $\mathrm{He}$ also comments that quantitative risk analyses are more expensive and time consuming, because they require keeping track of loan data both during loan origination and monitoring.

Quantitative analyses are often combined to create a "credit score," which quantifies the predicted risk of the borrower. Each creditscoring model provides the best predictions when it is individually developed for a particular bank's loans and lending practices (Coravos, 2010). Thus, the existing models assisting to quantitatively measure risk associated with SME lending cannot accurately be relied upon for default predictions if such exercises are not incorporated with qualitative measures of SME defaults. This position is mainly attributed to unavailability or confined accessibility to financial data and information of SME borrowers. 
As concluded by Dietsche and Petey (2004) who analyzed a set of German and French SMEs, SMEs are riskier but have a lower asset correlation with each other than large businesses. Hence, for many reasons SMEs are considered as different from large corporates and are increasingly subject to tailored approaches in default prediction. Altman and Sabato (2008) thus validated their hypothesis that applying a default prediction model developed on large corporate data to SMEs will result in lower prediction power and likely a poorer performance of the entire corporate portfolio than with separate models for SMEs and large corporates.

The main goal of this work is therefore to analyze MSME borrowers' characteristics captured by demographic and ownership information and to identify potential ability of such qualitative information to predict credit worthiness of entities in MSME sector. This study is driven by the importance for banks of predicting credit risk for MSMEs separately from large corporates. This research thus focuses on qualitative information and seeks to analyze credit repayment behavior of Micro and Small sized Enterprises using data from Trincomalee District of Sri Lanka. Analysis of credit repayment behavior based on qualitative information would be instrumental for predicting and evaluating credit risk or creditworthiness of borrowers especially when the borrowers are of small business and the lending is of relationship lending.

\section{Research Problem}

While a vast literature exists on credit risk modeling for large publicly-listed corporates, for whom relevant information is readily available to the researcher, literature on the credit risk of Small and Medium Enterprises (SMEs) has been relatively limited (McCann and McIndoe-Calder, 2012). In the contexts of increasing trend of SME lending as indicated in Financial System Stability Review -2012 of the Central Bank of
Sri Lanka and recent deterioration in assets quality of commercial banks by an increase in Non-Performance Loan as revealed in Sri Lanka Banking sector special report of Fitch rating in 2012, studies on SME credit risk should be considered as an important economic issue in Sri Lanka.

Prudent management of the risk on SME lending requires prediction of financial distress of borrowers from SMEs which in turn require published financial statements under applicable accounting standards which are difficult to be obtained in the contexts of the SMEs in Sri Lanka. Developing risk prediction models for SMEs therefore require to be based on or supplemented by non- accounting and qualitative information.

It is common that for most of the MSMEs the managers of the business are the owner/s of capital. Therefore MSMEs are highly depended on factors that influence the capacity, skills and attitudes of the owners of the business. Therefore the main question that this study seeks to address is whether MSMEs differ in credit repayment pattern depending on the differences in demographics of the SME borrower? Is "demographic information" a useful predictor of SMEs credit risk prediction?

\section{Research Objective}

Therefore the main objective of this paper is to examine the relationship between the demographic characteristics of borrowers in micro and small enterprises and their tendency on credit repayment or default. That is, to examine whether demographic information can be used to predict the credit repayment behavior of micro and small businesses.

\section{Review of Literature}

This study basically seeks to analyze the credit repayment behavior of MSME borrowers based on demographic information of owners of micro 
and small industry. Borrowers' demography and socio economic characteristics have been proved to matter in loan default. It is however noteworthy that this relationship has been studied in quite a lot of recent studies most of which have focused on students loan, consumer credit, housing loans,micro credit and commercial advances for micro small and medium enterprises etc.

Loan default studies on students' loan, consumer credit, housing loans micro credit have extensively focused the influence of demographic variables on loan repayment. Accordingly, borrowers' race has been found to have significant correlation with loan default according to Greene (1989), Wilms, Moore and Bolus (1987), Steiner and Teszler (2005) and Herr and Burt (2004). Gender is a significant factor in loan default according to many studies including Woo (2002), Podgursky et al. (2002), Steiner and Teszler (2005), and Herr and Burt (2004). Age tends to significantly and postively correlate with loan default rate according to Christman (2000), Harrast (2004), Herr \& Burt (2004), and Woo (2002). However, Knapp and Seaks (1992) found no relationship with age and default, while Steiner and Teszler (2005) found this pattern only among students older than 34 . However, Hillman (2012) claims that taken as a whole, race, age, and gender are likely to account for a degree of variation in default probability, but the nature of these relationships (particularly age and gender) is not entirely clear.

Similarly, the influences of demographic variables on loan repayment have also been a matter of academic research for many years. Pandy and Muralidharan (1979), using data from the Uttar Pradesh State in India, attempted to develop criteria for classifying borrowers as to their willingness to repay their loans on the basis of differences in their socio-economic characteristics. The discriminant function analysis indicated that the percentage of total income derived from sources other than crop production, the amount of loan, the purpose of loan, per capita consumption expenditure, and the ratio of cash expenditure to total expenditure were the major characteristics that classified borrowers into defaulter and non-defaulters.

Arene (1992) employed a regression analysis to identify the factors that significantly influence credit repayment performance of farmers associations in Anambra state in Nigeria and found that inter alia variables such as size of loan, income, education level and number of years of farming experience were statistically significant while distance and size of the households were not significant. Mbata (1994) had hypothesized that credit repayment performance from external source depends on duration of loan servicing, size or amount of credit obtained and income generated from the capital, while credit repayment performance from internal sources (member capital) depends on duration of membership, size of the household, amount of credit available, income generated from sales, gender of the household, income transfers received, the type of information and the extent of business diversification. Mbata (1994) employing standard probability model established that gender, amount of loan, member experience and household size were not statistically significant in various specification while crop sales, the size of enterprise, the degree of diversification, income transfers and quality of information were statistically significant. Nikhade et al. (1994) investigated crop loan repayment behavior among cotton growers with the aim of analysing behaviors and characteristics of borrowers along with the causes of non-repayment in crop loans. Relational analysis revealed that the social personal characteristics such as education, annual income, land holding and irrigation influenced positively the borrowing pattern and repayment behaviour of the borrowers.

Rambabu et al. (1994) studied factors influencing attitudes of the farmers towards farm credit with the aim of understanding the attitudes of the borrowers and non-borrowers towards farm credit. It was found that there is negative and significant relationship between age and attitudes 
of both borrowers and non-borrowers. it was further noted that education exposure to mass media and extension contact were found to be positively significant related with attitude of borrowers and non-borrowers. Harikumar (1991) investigated the utilization of loans, over dues and factors affecting proper repayment and over dues and found that socio-economic factors do not influence loan repayment. This conclusion however is contrary to that of Nikhade et al. (1994) and Rambabu et al. (1994). According to Harikumar (1991) crop failure and fall in prices were the major factors influencing loan defaulting.

According to Oni O.A et al., (2005) study on factors influencing loan default among poultry farmers in Ijebu Ode Local Government Area of Ogun State Nigeria; the result from the profit model revealed that flock size of the farmers significantly influence default in loan repayment at $(\mathrm{P}<0.10)$ level. Age of the farmers significantly influence default in loan repayment at $(\mathrm{P}<0.01)$ level, while Educational level and Income of the farmers also significantly influences default in loan repayment at $(\mathrm{P}<$ 0.05) level.

Papias and Ganesan (2008) employed primary data collected in rural Rwandan on variables contributing to the repayment behaviour in savings and cooperative societies and used a binary logistic regression empirical model to estimate the contribution of each variable to credit repayment rate. They showed that age, gender and size of the household, purpose for credit, interest rate charges and number of official visits to the credit societies, have a strong effect on loan repayment performance (statistically significant at $p, 0.05$ ) whereas size of credit disbursed, credit processing and disbursing time, borrowers' market place and income transfer from relatives and friends are more or less statistically significant at $\mathrm{p}, 0.20$ level.
Antwi at el (2012) studies the risk factors that influence loan default repayment among customers in Akuapem rural bank using secondary data from 2006 to 2010 and employed a logistic regression model. They found that Security and Type of Loan were significant to the study whereas Sex, Marital Status, Age, Educational Level, Town were not significant to the study.

\section{Research Model and Design}

Generally, a loan is said to be defaulted when it is not repaid or settled fully or partially as agreed. Broadly speaking, a loan is defaulted if the Expected Value of the loan(considering all factors that will bear on its 'value') envisaged at point of contract of loan is not fully or partly recovered (Intrinsic Value Loss) when the loan liability is discharged or deemed to be discharged.

SME Loan Repayment Risk (LRR), the dependent variable of this study,can therefore be analyzed into four discrete categories based on the parameters of Defaulted Repayment (DR) and Intrinsic Value Loss (IVL)to the lender. These categories can be explained by using the following 'loan repayment risk matrix (LRRM)' developed by the researcher for the purpose of approaching different categories of loan repayment risk.

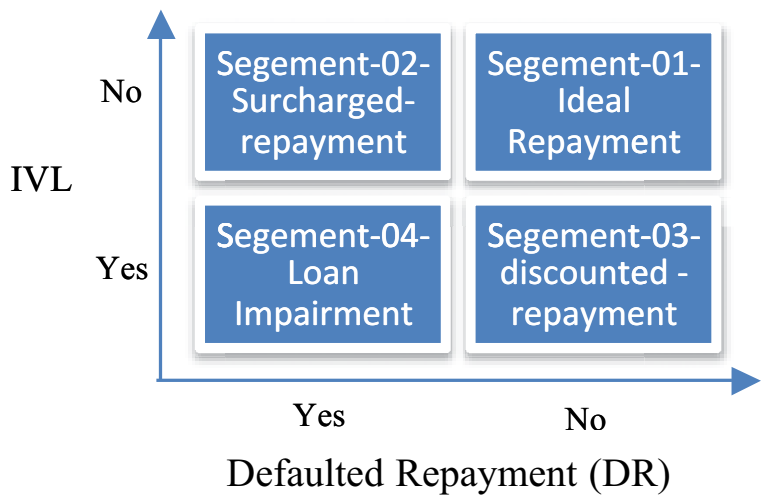

Figure 01: loan repayment risk matrix (LRRM)

Source: Author constructed 
The following table - 01 briefly describes the characteristics of the each segment of LRRM. It should be noted however that the segments in LRRM do not themselves indicate the magnitude of loss that will be resulted by corresponding credit risk. For example, a loan in segment - 03, 'discounted repayment' might be more disadvantageous in terms of monetary loss than those in segment, 'Loan Impairment' as those in segment-03 might be say larger in amount than the loan/s in segement-03.
On the other hand, Borrowers'Demographics, a independent variables of this research is proxied by gender, civil status, size of family (number of dependents), age and age group, ethnicity, education and mobility.Another independent variable is Ownership Information which, in this study, is represented by the nature of ownership of the enterprises that is, whether the business is of sole proprietorship or of partnership or of any other type.

Table 1:

Description of Repayment Risk Categories

\begin{tabular}{lll}
\hline Segement - 01 Ideal Repayment & $\begin{array}{l}\text { These are 'repayment risk free loans' in the sense that there } \\
\text { would be no contractual default in repayment and thereby no } \\
\text { IVL to the lender. Loans of this type are those generally } \\
\text { found settled in par with the terms of the loan agreement. }\end{array}$ \\
\hline Segement - 02 & $\begin{array}{l}\text { Surcharged- } \\
\text { repayment }\end{array}$ & $\begin{array}{l}\text { These types of loans are riskier as compared to the segment- } \\
01 \text { in the sense that there would be a DR of loanon the part } \\
\text { of the borrower but causing no IVL to the lender or the IVL } \\
\text { caused to the lender due to such default/s would be } \\
\text { compensated through surcharges imposed on defaulter. } \\
\text { Loans of this type are those generally, at least once, } \\
\text { classified as non- performing but later are recovered by the } \\
\text { Banks with surcharges attached to it which will compensate } \\
\text { the IVL. }\end{array}$
\end{tabular}

Segement-03 Discounted - These types of loans are riskier than those falling in repayment segment-01 and 02 in the sense that there would be no DR of loan on the part of the borrower but IVL to the lender could not be fully or partially compensated through surcharges imposed on defaulter. This may be because of reasons that for example the 'lender does not have right to impose such surcharges' on the borrower. Loans of this type are those generally affected by some mistakes or defaults or unexpected developments from the part of the lender which ultimately deprive the right of the lender to claim damages over any IVL

$\begin{array}{ll}\text { Segement - 04 } & \text { Loan } \\ & \text { Impairment }\end{array}$

These are 'repayment riskiestloans' as compared to the segment-01, 02 and 03 in the sense that there would be a DR of loan on the part of the borrower and the IVL to the lender due to such default/s could not be fully or partially compensated through surcharges imposed on defaulter due to bankruptcy of the borrower . 
Gender; Women are also able to budget well their income at the household level and it is expected that women who are involved in credit schemes are more likely to repay their loans successfully than men (Papias and Ganesan, 2008).

Civil status; is expected to increase the capacity of the MSME borrower as the spouse will provide a support to the business and therefore may be expected to improve the performance of the business and thereby enhancing creditworthiness of the borrower

Family Size; The size of household has an ambiguous expectation (Papias and Ganesan, 2008). In one hand, it is hypothesised that as household size increases, income earning capacity also increases given that the number of dependent members remains constant. On the other hand the increase in the number of households' members who are dependent would reduce the income earning capacity and thereby becoming credit unworthy (Zeller, 1995). Therefore though Size of the borrower's family is an important indication of the capacity of borrower with more dependents attached to his maintenance may negatively impact on the business as borrower may often draft from the business capital and retained earnings thereby negatively affecting business prospects and credit worthiness.

Age; Age is expected to increase his productivity and thus to exert creditworthiness in the face of lenders (Gershon et al., 1988). In the other words, age is translated into an experience of the borrower in the economic activities being financed (Papias and Ganesan, 2008).

Ethnicity; Ethnic background of the borrower is expected to influence the attitude and morale towards the repayment of a loan.

Education; Education level or qualification of the owner of borrowing MSME is expected to impact his knowledge, skill and attitude thereby impacting on the business success. The number of years of formal schooling is an indicator of human capital, which affects positively efficiency (Gershon et al., 1988). In addition to this, educated farmer are expected to adopt new production technologies that increase returns from agricultural production (Arene, 1992 and $\mathrm{Njoku}$, 1997). For these reasons, education would be an indicator of creditworthiness, and would increase repayment capacity of the borrowers (Papias and Ganesan, 2008).

Mobility;Mobility has been included as demographic information and measured by the distance between the lender and enterprise location. When there prevail more distance between borrower and lender, less coordination and monitoring of the performance of loan would be possible. This will bear an impact on the credit repayment behavior of the borrower.

\begin{tabular}{|c|c|}
\hline & Gender \\
\hline & Civil Status \\
\hline & Size of Family \\
\hline Owner & Age and age group \\
\hline Demographics & Ethnicity \\
\hline & Language \\
\hline & Education \\
\hline & Distance from lender \\
\hline Ownership & Nature of ownership \\
\hline Information & (Sole Trade/Partnership/Other) \\
\hline
\end{tabular}

\section{Figure 02: Summary of Research Variables}

The objective of the analys is therefore would be to investigate whether owners' demographics and ownership information of borrowing MSMEs determine 'the repayment risk segment' that it takes in LRRM.

The Borrowers and loan characteristics, the independent variables are mostly of discrete category. Therefore, Chi-Square Test, an appropriate non-parametric test for the investigations with data of this nature, is employed to examine the relationship between dependent and independent variables and where the independent variables take continues values (distance between borrower and lender), the relationship is tested with one-way analysis of variance (ANOVA) with post hoc comparison using Turkey's honestly significant difference (HSD) test. Data analysis has been performed using SPSS (version 15.0) 
Data was collected from randomly selected 62 SMEs that borrowed from commercial banks in Trincomalee District of Sri Lanka. The sample of 62 SMEs constituted to nearly $10 \%$ of total MSME borrowers from the Bank studied and the samples were drawn proportional to the size of each segment in LRRM during the period of 10 years from the year 2000. Due to unavailability of information about the loan falling in the segment -03, 'Discounted -repayment', that segment has been excluded from the scope of this study. Thus, as provided in Table 02, the sample represents 24 enterprises in segment -01 , 'ideal repayment' and 18 organizations in segment -02, 'Surcharged- repayment' and 20 enterprises in segment -04, 'loan impairment' and zero number of enterprise in segment-03,

'Discounted-repayment.

\section{Results and Discussions}

Except for identifying the relationship between the distance of the borrowing SME from lending institution and the repayment risk, the relationship between repayment risk and all such other independent valuables as Borrowers' Gender, Age, Education, Ethnicity, Language, Civil Status, Family Size and Ownership has been tested using Chi-Square, that belong to the family of univariate analysis. The results obtained are summarized in the Table 04 and proceeding section of this paper seeks to interpret the statistics with the assistance of cross tabulation of research data.

Table 02:

Loan Repayment Risk categories when reduced into three segments

\begin{tabular}{ccc}
\hline Risk Categories & $\begin{array}{c}\text { Corresponding segment/s in } \\
\text { LRRM }\end{array}$ & $\begin{array}{c}\text { Sample number of } \\
\text { MSMEs }\end{array}$ \\
\hline Ideal Repayment & Segment -01 & 24 \\
\hline Surcharged Repayment & Segment -02 & 18 \\
\hline Loan Impairment & Segment -04 & 20 \\
\hline & Total & 62 \\
\hline
\end{tabular}

However, due to the limitation in the sample size corresponding to other three segments in the LRRM which have been included for this study, when performing Chi-Square Test, where the expected count less than 5 is not zero which is an essential test assumption, the Loan Repayment Risk categories that make up the sample were reduced into two segments as in the Table 03 below so that the said test assumption is not violated.

Table 03:

Loan Repayment Risk categories when reduced into two segments

\begin{tabular}{ccc}
\hline Risk Categories & $\begin{array}{c}\text { Corresponding segment/s in } \\
\text { LRRM }\end{array}$ & $\begin{array}{c}\text { Sample number of } \\
\text { MSMEs }\end{array}$ \\
\hline Ideal Repayment & Segment -01 & 24 \\
\hline Risky Repayment & Segment -02 \& Segment -04 & 38 \\
\hline & Total & 62 \\
\hline
\end{tabular}


Table 04: Results

\begin{tabular}{|c|c|c|c|c|c|}
\hline & $\begin{array}{l}\text { Pearson } \\
\text { Chi- } \\
\text { Square } \\
x^{2}\end{array}$ & $\begin{array}{l}\text { Asymp. } \\
\text { Sig. } \\
\text { (2-sided) }\end{array}$ & $\begin{array}{l}\text { Fisher's } \\
\text { Exact Test } \\
\text { Sig. } \\
\text { (2 sided) }\end{array}$ & $F$ & Sig \\
\hline Gender & 6.649 & $.010^{* *}$ & .009 & & \\
\hline Borrowers' Age Group & 9.885 & $.007 * *$ & & & \\
\hline Borrowers' Education & 6.318 & $.042 *$ & & & \\
\hline Ethnicity & 5.274 & .072 & & & \\
\hline Language & 5.194 & $.023 *$ & .025 & & \\
\hline Civil Status & 1.360 & .243 & & & \\
\hline \multicolumn{6}{|l|}{ Family Size } \\
\hline number of dependents $>1$ & 0.654 & .419 & & & \\
\hline number of dependents $>2$ & 0.654 & .419 & & & \\
\hline number of dependents $>3$ & 0.944 & .331 & & & \\
\hline number of dependents $>4$ & 1.305 & .253 & & & \\
\hline Ownership & 9.663 & $.008 * *$ & & & \\
\hline Distance & & & & 4.580 & $.014^{*}$ \\
\hline
\end{tabular}

*Significance at $\mathrm{p}<0.05$ percent

$* *$ Significance at $\mathrm{p}<0.01$ percent

\section{Borrowers' Gender}

The relationship between Borrowers' gender and LRR has been analyzed with LRR grouped into two segments, the Ideal Repayment and Risky Repayment. The following cross tabulation was obtained with the data. there was still one cell which has expected count less than 5 which therefore required the reference of Fisher's Exact Test statistics to establish the significance of the relationship. As Fisher's Exact Test statistics (0.009 (2 sided) and 0.008 (1-sided)) was also below the alpha value of 0.05 the relationship between the variables can be

Table 05:

Cross Tabulation -Borrowers' Gender

\begin{tabular}{lllll}
\hline $\begin{array}{l}\text { Loan Repayment } \\
\text { Risk Segments }\end{array}$ & Female & Male & \multirow{2}{*}{ Total } \\
\hline \multirow{2}{*}{ Ideal } & Count & 0 & 24 & 24 \\
Repayment & $\%$ within the Segment & $.0 \%$ & $100.0 \%$ & $100.0 \%$ \\
& $\%$ within Gender & $.0 \%$ & $45.3 \%$ & $38.7 \%$ \\
\hline \multirow{2}{*}{ Risky } & Count & 9 & 29 & 38 \\
Repayment & $\%$ within the Segments & $23.7 \%$ & $76.3 \%$ & $100.0 \%$ \\
& $\%$ within Gender & $100.0 \%$ & $54.7 \%$ & $61.3 \%$ \\
\hline
\end{tabular}

Accordingly, SME loan repayment risk significantly correlates with gender of the borrowers at Pearson Chi-Square of 6.649 with $\mathrm{p}$-value of 0.01 which is below 0.05 alpha value. $\left(x^{2}=6.649, \mathrm{p}=0.01<0.05\right.$, alpha). It is noted that confidently stated to be statistically significant. This finding indicates that female led MSME borrowers are most likely to become into Risky Repayment Segments than into Ideal Repayment in LRRM. 


\section{Borrowers' Age}

The relationship between Borrowers' age and LRR is examined where LRR is grouped into three segments; the Ideal repayment, Surcharged repayment and Loan Impairment. It was found that $26.1 \%$ of borrowers within the age group of 40 and below fall within Ideal Repayment Segment whereas Segments -02 and Segments 04 respectively incorporate $17.4 \%$ and $56.5 \%$ of 40 and below age group. Of those within above 40 age group, 46.2\%, 35.9\% and $17.9 \%$ becomes respectively into Ideal Repayment, Surcharged Repayment and Loan Impairment segments.
However, it is found that there exists no significant difference in the mean age of the borrowers in different segments of LRRM when loan repayment risk was analyzed by two segments; that is, Ideal repayment and other using independent-group t-test, $(\mathrm{t}(\mathrm{df}=60)$ $=1.477, \mathrm{p}=0.145>0.05)$. Similarly, the same conclusion was obtained when the difference in the mean age of the borrowers in all four segments of LRRM is examined using One-way ANOVA between groups, $(\mathrm{F}(\mathrm{df}=2,59)=2.387$, $\mathrm{p}=0.101>0.05$ ).

Table 06:

Cross Tabulation -Borrowers' Age

\begin{tabular}{lllll}
\hline $\begin{array}{l}\text { Loan Repayment } \\
\text { Risk Segments }\end{array}$ & $\begin{array}{l}\text { Age Group -01 } \\
(\text { Age }<=40)\end{array}$ & $\begin{array}{l}\text { Age Group -02 } \\
\text { Age }>41\end{array}$ & Total \\
\hline \multirow{2}{*}{$\begin{array}{l}\text { Ideal } \\
\text { repayment }\end{array}$} & Count & 6 & 18 & 24 \\
& $\%$ within the Segment & $25.0 \%$ & $75.0 \%$ & $100.0 \%$ \\
& $\%$ within Age Group & $26.1 \%$ & $46.2 \%$ & $38.7 \%$ \\
\hline \multirow{2}{*}{ Surcharged } & Count & 4 & 14 & 18 \\
repayment & $\%$ within the Segment & $22.2 \%$ & $77.8 \%$ & $100.0 \%$ \\
& $\%$ within Age Group & $17.4 \%$ & $35.9 \%$ & $29.0 \%$ \\
\hline \multirow{2}{*}{ Loan } & Count & 13 & 7 & 20 \\
& $\%$ within the Segment & $65.0 \%$ & $35.0 \%$ & $100.0 \%$ \\
& $\%$ within Age Group & $56.5 \%$ & $17.9 \%$ & $32.3 \%$ \\
\hline
\end{tabular}

Borrowers' Age significantly associates with LRR when the borrowers were categorized into two age groups; those aged less than and equal to 40 and those aged more than 41. As provided in Chi-Square table below, the correlation is significant at Pearson Chi-Square of 9.885 and $\mathrm{p}$ value of $0.007\left(x^{2}=9.885, \mathrm{p}=0.007<0.01\right.$, alpha). These statistics indicate that those of ' 40 and below age group' are more likely to become into Segment- 02 and Segment- 04 of LRRM than into Segment- 01. Borrowers within Ideal Repayment segment are most likely to be of 'above 41 age group'.

\section{Borrowers' Education}

The relationship between Borrowers' education qualification and LRR has been tested having LRR grouped into two segments, the ideal repayment and risky repayment. Borrowers' educational level was measured through the level of completion of formal education. Thus, borrowers in each risk segment were analyzed into three discrete categories of educational level which are 'Below Ordinary level $(\mathrm{O} / \mathrm{L})$ ', ' $\mathrm{O} / \mathrm{L}$ ' and 'Advanced Level (A/L) and Above'. The following cross tabulation was obtained with the data used for analysis. 
Table 07:

Cross Tabulation -Borrowers' Education

\begin{tabular}{|c|c|c|c|c|c|}
\hline $\begin{array}{l}\text { Risk } \\
\text { Segments }\end{array}$ & & $\begin{array}{l}\text { Below } \\
\mathrm{O} / \mathrm{L}\end{array}$ & $\mathrm{OL}$ & $\begin{array}{l}\mathrm{A} / \mathrm{L} \text { and } \\
\text { above }\end{array}$ & Total \\
\hline \multirow{3}{*}{$\begin{array}{l}\text { Ideal } \\
\text { repayment }\end{array}$} & Count & 8 & 3 & 13 & 24 \\
\hline & \multirow{2}{*}{$\begin{array}{l}\% \text { within the Segment } \\
\% \text { within Education } \\
\text { Qualification }\end{array}$} & $33.3 \%$ & $12.5 \%$ & $54.2 \%$ & $100.0 \%$ \\
\hline & & $44.4 \%$ & $15.8 \%$ & $52.0 \%$ & $38.7 \%$ \\
\hline \multirow{4}{*}{$\begin{array}{l}\text { Risky } \\
\text { repayment }\end{array}$} & Count & 10 & 16 & 12 & 38 \\
\hline & \multirow{3}{*}{$\begin{array}{l}\% \text { within the Segment } \\
\% \text { within Education } \\
\text { Qualification } \\
\text { Total }\end{array}$} & $26.3 \%$ & $42.1 \%$ & $31.6 \%$ & $100.0 \%$ \\
\hline & & $55.6 \%$ & $84.2 \%$ & $48.0 \%$ & $61.3 \%$ \\
\hline & & 18 & 19 & 25 & 62 \\
\hline
\end{tabular}

Accordingly it was found that $54.2 \%$ of the borrowers in ideal repayment segment possess Advanced Level (A/L) qualification and more. At the same time $55.6 \%$ of the borrowers with educational qualification below ordinary level $(\mathrm{O} / \mathrm{L})$ fall into other segments which are riskier than ideal repayment segment in LRRM. Educational qualification significantly correlates with LRR at Pearson Chi-Square of 6.318 with $\mathrm{p}$-value of $0.042\left(x^{2}=6.318, \mathrm{p}=0.042<0.05\right.$, alpha).

This implies that the more the education qualification possessed by the owners of MSMEs the less would be the loan repayment risk and viz.

\section{Borrowers' Civil Status and Ethnicity}

Borrowers' civil status has been found to have not significantly associated with LRR where LRR was again grouped into two segments, the ideal repayment and other segments in LRRM $\left(x^{2}=1.360, \mathrm{p}=0.243>0.05\right.$, alpha $)$.
Borrowers' ethnicity and LRR is not significant at alpha level of $0.05\left(x^{2}=5.274, p=0.072>0.05\right.$, alpha). For this purpose, borrowers were analyzed into three different ethnic groups of the district under study; 'Sinhalese', 'Tamils' and 'Muslims and Others' and LRR was grouped into two segments, the Ideal repayment and Risky repayment.

\section{Borrowers' Native Language}

The relationship between Borrowers' language and LRR has been tested having LRR grouped into two segments, the ideal repayment and risky repayment. Language diversity of borrowers was studied into two discrete categories of 'Language predominantly spoken in the district' and 'Language other than predominantly spoken in the district' and the following cross tabulation was obtained with the data used for analysis. 
Table 08:

Cross Tabulation -Borrowers' Native Language

\begin{tabular}{|c|c|c|c|c|}
\hline $\begin{array}{l}\text { Risk } \\
\text { Segments }\end{array}$ & & $\begin{array}{l}\text { Language } \\
\text { Predominantly } \\
\text { spoken in the district }\end{array}$ & $\begin{array}{l}\text { Language other than } \\
\text { predominantly } \\
\text { spoken in the district }\end{array}$ & Total \\
\hline \multirow{3}{*}{$\begin{array}{l}\text { Ideal } \\
\text { repayment }\end{array}$} & Count & 21 & 3 & 24 \\
\hline & $\%$ within the Segment & $87.5 \%$ & $12.5 \%$ & $100.0 \%$ \\
\hline & $\%$ within Language & $47.7 \%$ & $16.7 \%$ & $38.7 \%$ \\
\hline \multirow{4}{*}{$\begin{array}{l}\text { Risky } \\
\text { repayment }\end{array}$} & Count & 23 & 15 & 38 \\
\hline & $\%$ within the Segment & $60.5 \%$ & $39.5 \%$ & $100.0 \%$ \\
\hline & $\%$ within Language & $52.3 \%$ & $83.3 \%$ & $61.3 \%$ \\
\hline & Total & 44 & 18 & 62 \\
\hline
\end{tabular}

Accordingly, it was found that $87.5 \%$ of the MSME borrowers in ideal repayment segment speak language predominantly spoken in the district as their native language where as in Trincomalee district $83.3 \%$ of those MSME borrowers having 'language other than predominantly spoken in the district' as their native language have fallen into Risky repayment. It is noted that within Risky repayment segment $60.5 \%$ of MSME borrowers are of Speaking the language predominantly spoken in the district and it is $87.5 \%$ within idea repayment segment. It is noted that the languages spoken in Trincomalee districtare Tamil and Sinhala.

Language differences significantly correlates with LRR at Pearson Chi-Square of 5.194 with p-value of $0.023\left(x^{2}=5.194, \mathrm{p}=0.023<0.05\right.$, alpha). This implies that lending for MSMEs with owner who speaks a language other than that is predominantly spoken in the respective district may be more riskier than for MSMEs with owner who speaks a language that is predominantly spoken in the respective district and viz.

\section{Borrowers' Family size}

The relationship between Borrowers' Family size and LRR (categorized into two segments, the ideal repayment and other segments in LRRM) is also not significant even as borrowers' family size was analyzed in four dimensions which are 'Borrowers having one or no child and Borrowers having more than a child' $\left(x^{2}=0.654\right.$, $p=0.419>0.05$, alpha), 'Borrowers having two or less than two children and Borrowers having more than two children' $\left(x^{2}=0.654, \mathrm{p}=0.419>\right.$ 0.05 , alpha), 'Borrowers having three or less than three number of children and Borrowers having more than three children' $\left(x^{2}=0.944\right.$, $\mathrm{p}=0.331>0.05$, alpha) and 'Borrowers having four or less than four number of children and Borrowers having more than four children' $\left(x^{2}=\right.$ $1.305, \mathrm{p}=0.253>0.05$, alpha).

\section{Mobility}

Mobility has been included as demographic information and measured by the distance in $\mathrm{Km}$ between the lender and enterprise location. ANOVA with post-hoc comparison reveled that there is significant differences in the mean distance of the MSME borrowers falling in different segments of the LRRM. $[\mathrm{F}(\mathrm{df}=2,51)=$ $4.580, p=.014<0.01)]$. Tukey HSD test result is summarized in the table below. 
Table 09:

Tukey HSD test result for mobility differences

\begin{tabular}{lllll}
\hline $\begin{array}{l}\text { Loan Repayment Risk } \\
\text { Segments (I) }\end{array}$ & $\begin{array}{l}\text { Loan Repayment Risk } \\
\text { Segments Compared (J) }\end{array}$ & $\begin{array}{l}\text { Mean } \\
\text { Difference } \\
(\mathrm{I}-\mathrm{J})\end{array}$ & Std. Error & Sig. \\
\hline Ideal repayment & Surcharged repayment & $-30.84722^{*}$ & 10.19342 & .010 \\
& Loan Impairment & -13.70833 & 9.89790 & .355 \\
\hline Surcharged repayment & Ideal repayment & $30.84722^{*}$ & 10.19342 & .010 \\
& Loan Impairment & 17.13889 & 10.62130 & .248 \\
\hline Loan Impairment & Ideal repayment & 13.70833 & 9.89790 & .355 \\
& Surcharged repayment & -17.13889 & 10.62130 & .248 \\
\hline
\end{tabular}

\section{Ownership Information}

The relationship between nature of ownership and LRR has been tested having LRR grouped into three segments, the ideal repayment, surcharged repayment and loan impairment. Nature of ownership of MSMEs under study was studied into three discrete categories of soletrade, partnership and company and other. It is noted that no MSME under this study was registered as company and the following cross tabulation was obtained with the data used for analysis.
Surcharged repayment segment and $45 \%$ in Loan Impairment group. It was also found that within proprietorship MSMEs $45.5 \%$ of the MSMEs are in Ideal repayment segment and it is $34.1 \%$ for Surcharged repayment and $20.5 \%$ in the Loan Impairment. Similarly, within partnership MSMEs $61.1 \%$ of the MSMEs are identified within the Loan Impairment segment and it is $16.7 \%$ and $22.2 \%$ for Surcharged repayment and $20.5 \%$ in ideal repayment respectively.

Ownership information significantly correlates with LRR at Pearson Chi-Square of 9.663 with $\mathrm{p}$-value of $0.008\left(x^{2}=9.663, \mathrm{p}=0.008<0.01\right.$,

Table 10:

Cross Tabulation - Ownership Information

\begin{tabular}{lllll}
\hline $\begin{array}{l}\text { Risk } \\
\text { Segments }\end{array}$ & $\begin{array}{l}\text { Sole- } \\
\text { proprietorship }\end{array}$ & Partnership & Total \\
\hline \multirow{2}{*}{$\begin{array}{l}\text { Ideal } \\
\text { repayment }\end{array}$} & Count & 20 & 4 & 24 \\
& \% within the Segment & $83.3 \%$ & $16.7 \%$ & $100.0 \%$ \\
& \% within Type of Ownership & $45.5 \%$ & $22.2 \%$ & $38.7 \%$ \\
\hline \multirow{2}{*}{$\begin{array}{l}\text { Surcharged } \\
\text { repayment }\end{array}$} & Count & 15 & 3 & 18 \\
& \% within the Segment & $83.3 \%$ & $16.7 \%$ & $100.0 \%$ \\
\multirow{2}{*}{$\begin{array}{l}\text { Loan } \\
\text { Impairment Type of Ownership }\end{array}$} & $34.1 \%$ & $16.7 \%$ & $29.0 \%$ \\
\hline & Count & 9 & 11 & 20 \\
& \% within the Segment & $45.0 \%$ & $55.0 \%$ & $100.0 \%$ \\
& Total & $20.5 \%$ & $61.1 \%$ & $32.3 \%$ \\
\hline
\end{tabular}

Accordingly, it was found that $83.3 \%$ of the MSMEs in ideal repayment segment are of soleproprietorship and it is again $8.3 \%$ within alpha). This implies that lending for MSMEs with sole- proprietorship is less riskier than for Partnership viz. 


\section{Conclusion}

Credit Repayment Risk can be broadly approached using the Loan Repayment Risk Matrix (LRRM) introduced in this paper. Empirical analysis has been guided by this framework and has revealed that owners' gender, age, education, language and mobility and ownership information are significantly correlating with loan default risk of MSMEs while statistically significant relationship is not confirmed with respect to civil status, ethnicity and family size. Therefore empirical analysis can be summarized as that MSMEs with female owners and or with the owners of ' 40 and below age group' and or with education qualification below Ordinary level and or with owner who speaks a language other than that is predominantly spoken in the respective district and or relatively far-distanced from the lender and or of partnership in ownership may carry relatively higher risk in credit repayment.

Therefore, the owners' demographics and ownership information of MSME have explanatory power over credit repayment behavior of MSME in Trincomalee district and hence could be considered for assessing the credit worthiness of MSME applications for credit or in designing recovery measures thereof. This research is recommended to be replicated based on Loan Repayment Risk Matrix in other districts of the country and elsewhere in the globe with increased number of sample analyzed with multivariate models.

\section{References}

Altman, E.I., Sabato, G. and Wilson, N. (2008), 'Value of qualitative information in SME risk management', Journal of Financial Services Research, Vol. 28 (1/3)

Antwi, S, Mills, AEFE, Mills, AG and Zhao,X, (2012), 'Risk factors of loan default payment in Ghana: a case study of Akuapem Rural Bank', International Journal of Academic Research in Accounting, Finance and Management Sciences, Vol. 2, No. 4.

Arene, C.J. (1992), 'Loan repayment and technical assistance among smallholder maize farmers in Nigeria', African Review of Money Finance and Banking, A supplement of Savings and Development Journal, Vol. 1, pp. 64-72.

Berger, A.N. Udell, G.F. (2006), 'A more complete conceptual framework for SME finance', Journal of Banking and Finance.

Central Bank of Sri Lanka, Financial System Stability Review, 2012 http://www.cbsl.gov.lk/ pics_n_docs/10_pub/_docs/efr/financial_syste m_stability_review/fssr_2012e.pdf

Christman, D.E. (2000), 'Multiple realities: characteristics of loan defaulters at a two-year public institution', Community College Review, 27(4), 16.

Coravos, A.R. 2010, Measuring the Likelihood of Small Business Loan Default: Community Development Financial Institutions (CDFIs) and the use of Credit-Scoring to Minimize Default Risk, Economic Hons Thesis, Duke University, Durham, North Carolina.

Gershon, F., Onchan, T. and Raparla, T. (1988), 'Collateral, guarantees and rural credit in developing countries: evidence from Asia', Agricultural Economics, Vol. 2, pp. 231-45.

Greene, L.L. 1989, 'An economic analysis of student loan default', Educational Evaluation and Policy Analysis, 11(1), 61. 
Harikumar, S. (1991), 'Utilization and repayment of agricultural loans of regional rural banks: a case study', Agricultural Banker, October/December, pp. 13-16.

Harrast, S.A. (2004), 'Undergraduate borrowing: a study of debtor students and their ability to retire undergraduate loans', NASFAA Journal of Student Financial Aid, 34(1), 21-37.

Herr, E. Burt, L. 2004, 'Predicting student loan default for the University of Texas at Austin', NASFAA Journal of Student Financial Aid, 2, pp. 27-49.

Hillman, W.M. (2012), 'College on credit: a multilevel analysis of student loan default', University of Utah, Salt Lake City

Knapp, L.G. Seaks, T.G. (1992), 'An Analysis of the Probability of Default on Federally Guaranteed Student Loans', The Review of Economics and Statistics, Vol.74, No. 3, pp. 404-411.

McCann, F. McIndoe-Calder, T. (2012), 'Determinants of SME Loan Default: The Importance of Borrower-Level Heterogeneity' Resaech Technical Paprer, Central Bank of Ireland.

Nikhade, D.M. Shinde, P.S. and Nighot, S.M. (1994), 'Crop loan repayment behaviour in cotton growers', Agricultural Banker, October/December, pp. 13-16.

Njoku, J.E. (1997), 'Determinants of loan repayment under the special emergency loan scheme (SEALS) in Niger: a case study in Imo state', African Review of Money Finance and Banking, Vol. 1, pp. 39-51.

Oni, O.A. Oladele, O.I. and Oyewole, I.K. (2005), 'Analysis of factors influencing farmers in Ogum state Nigeria', Dept of Agricultural Economics, University of Ibadan Nigeria.

Pandy, U.K. Muralidharan, M.A. (1979), 'An Application of Discriminant Function In Agricultural Finance', Indian Journal of Agricultural Economics.
Papias, M.M. Ganesan, P. (2008), 'Repayment behaviour in credit and savings cooperative societies empirical and theoretical evidence from rural Rwanda', International Journal of Social Economics, Vol. 36, No. 5.

Podgursky, M. Ehlert, M. Monroe, R. Watson, D. and Wittstruck, J. (2002), 'Student loan defaults and enrollment persistence'.Journal of Student Financial Aid, Vol.32, No.3, pp.27-42.

Rambabu, P.D. Eswaran, Y.P. (1994), 'Factors influencing attitude of the farmers towards farm credit', Agricultural Banker, October/December, pp. 25.

Steiner, M. Teszler, N. (2005), 'Multivariate analysis of student loan defaulters at Texas', A\&M University.Austin, TX. January.

Wilms, W.W. Moore, R.W. Bolus, R.E. (1987), 'Whose fault is default?a study of the impact of student characteristics and institutional practices on guaranteed student loan default rates in California', Educational Evaluation and Policy Analysis, Vol. 9, No. 1, pp 41-54.

Woo, J.H. (2002), 'Factors Affecting the Probability of Default: Student Loans in California', Journal of Student Financial Aid, Vol. 32, No. 2, pp. 5-23.

Zeller, M. (1995), 'The demand for financial services by rural households - conceptual framework and empirical findings', Quarterly Journal of International Agriculture, Vol. 34, No. 2, pp. 149-70. 